\title{
PENGARUH KUALITAS PRODUK TERHADAP KEPUASAN, REPUTASI MEREK DAN LOYALITAS KONSUMEN JAMU TOLAK ANGIN PT. SIDO MUNCUL
}

\author{
Budi Hermawan \\ Program Studi Manajemen, Institut Bisnis dan Informatika Indonesia (IBII)
}

\begin{abstract}
One of the key factor that PT Sido Muncul concerns about its Jamu Tolak Angin is the customer loyalty. The increase number of loyal customers can be considered as the success of the company's product amidst the competition. This research is conducted to find out whether the product's quality influences the customer loyalty through customer satisfaction and brand reputation of the PT Sido Muncul's Jamu Tolak Angin brand.
\end{abstract}

This research is conducted to retest the model proposed by Fred Selnes (1993), by using the Structural Equation Model (SEM). The sample of this research is 200 persons, collected by judgment sampling.

The result of this research shows that customer loyalty is influenced by product quality, customer satisfaction, and brand reputation. Product quality influences customer loyalty through customer satisfaction and brand reputation. The model's test of this research shows Chi-Square $=65.81 \quad(P=0.00026), \quad R M S E A=0.071, G F I=0.94$, dan $A G F I=0.90$. Product quality influences customer loyalty through customer satisfaction and brand reputation by 0.26 and it influences customer loyalty through brand reputation by 0.46 .

This research shows that good quality product will lead to the increase of customer loyalty and brand reputation of the PT Sido Muncul's Jamu Tolak Angin brand. Loyal customers are directly influenced by PT Sido Muncul's Jamu brand, while customer satisfaction doesn't directly influence customer loyalty. When choosing which jamu product to consume, the customers don't necessarily choose the product based on the satisfaction of past use but on the brand reputation. Customers think that the jamu brand that has good reputation is suitable for continuous use. This is because customers view jamu as traditional medicine, so the selection should be based on those products who have reliable brand reputation. This result shows that the PT Sido Muncul's Jamu Tolak Angin brand reputation that has been formed may strengthen the product quality's influence on creating customer loyalty.

Keywords : Product Quality, Customer Loyalty, Customer Satisfaction, Brand Reputation.

\section{PENDAHULUAN}

Latar Belakang

Banyaknya produk perusahaan jamu yang menawarkan varians produk yang sama membuat persaingan semakin ketat. Suatu kewajaran jika perusahaan yang berada pada masa hyper competition seperti saat ini menyiapkan berbagai kegiatan untuk mempertahankan diri agar tetap dapat eksis di pasar. Sehingga setiap perusahaan melakukan kegiatan pemasarannya dengan sangat serius agar dapat memenangkan persaing tersebut. Salah satu faktor kunci yang menjadi perhatian PT. Sido Muncul dalam hal ini produk jamu tolak angin adalah loyalitas pelanggan.

Secara teori loyalitas pelanggan merupakan satu faktor yang dapat memberikan berbagai keuntungan bagi pemasar. Loyalitas ini merupakan perilaku pasca pembelian atau penggunaan produk. Bentuk dari loyalitas yang dapat terlihat secara empiris adalah pembelian ulang dan perekomendasian. Loyalitas konsumen terhadap suatu produk tidak serta merta akan timbul, terutama untuk jenis produk convinience. Maka dibutuhkan usaha untuk menbangun dan mempertahankan loyalitas tersebut. 
Beberapa hal yang menjadi perhatian jamu tolak angin dalam membangun serta mempertahankan loyalitas konsumennya adalah kualitas dari produk jamu tolak angin, reputasi merek tolak angin dan kepuasan konsumen jamu tolak angin. Sejatinya hal-hal tersebut dapat meningkatkan loyalitas pada jamu tolak angin.

Penelitian ini mereplikasi penelitian Selnes(1993). Tujuannya adalah menguji kembali apakah model yang dikemukakan Selnes cukup relevan digunakan untuk mengukur Loyalitas Konsumen. Perbedaan penelitian ini dengan penelitian yang direplikasi adalah pengujian pada penelitian ini dibatasi hanya untuk produk Jamu Tolak Angin PT. Sido Muncul.

\section{Perumusan Masalah}

Masalah dalam penelitian ini dirumusakan dalam bentuk pertanyaan penelitian sebagai berikut:

1. Apakah kualitas produk berpengaruh positif terhadap loyalitas konsumen melalui kepuasan konsumen Jamu Tolak Angin PT. Sido Muncul?

2. Apakah kualitas produk berpengaruh positif terhadap loyalitas konsumen melalui reputasi merek Jamu Tolak Angin PT. Sido Muncul?

3. Apakah kualitas produk berpengaruh positif terhadap loyalitas konsumen melalui kepuasan konsumen dan reputasi merek Jamu Tolak Angin PT. Sido Muncul?

\section{Manfaat Penelitian}

Hasil penelitian ini diharapkan dapat memberikan kontribusi pada pengembanganilmu, terutama pada bidang ilmu Manajemen Pemasaran. Model yang digunakan dalam penelitian ini diharapkan dapat memberikan struktur yang memadai dalam mengukur pengaruh loyalitas konsumen untuk produk convinience, dan juga diharapkan bisa dipakai sebagai acuan untuk riset-riset mendatang.

Di samping itu hasil dari penelitian ini diharapkan dapat memberikan kontribusi praktis bagi organisasi dalam pengambilan keputusan sehubungan dengan meningkatkan loyalitas konsumen khususnya pada industri jamu. Selanjutnya akan diuraikan tentang telaah pustaka dan pengembangan hipotesis, metode penelitian, hasil dan pembahasan dan kesimpulan dan saran.

\section{TELAAH PUSTAKA, KERANGKA KONSEP, DAN HIPOTESIS}

\section{Kualitas Produk}

Kualitas merupakan totalitas fitur dan karakteristik yang yang mampu memuaskan kebutuhan, yang dinyatakan maupun tidak dinyatakan, kualitas mencakup pula daya tahan produk, kehandalan, ketepatan, kemudahan operasi dan perbaikan, serta atributatribut nilai lainnya. Beberapa atribut itu dapat diukur secara obyektif. Dari sudut pandangan pemasaran, kualitas harus diukur sehubungan dengan persepsi kualitas para pembeli (Kotler dan Keller, 2006; Ahyari, 1990; Assauri, 1998).

\section{Reputasi Merek}

Reputasi merupakan penghargaan yang didapat oleh perusahaan karena adanya keunggulan-keunggulan yang ada pada perusahaan tersebut, seperti kemampuan yang dimiliki oleh perusahaan, sehingga perusahaan akan terus dapat mengembangkan dirinya untuk terus dapat menciptakan hal-hal yang baru lagi bagi pemenuhan kebutuhan konsumen. (Herbig dan Milewicz, 1993). Perusahaan dapat membangun berbagai macam reputasi, seperti reputasi kualitas, reputasi pemasaran, reputasi inovasi produk, dan lain 
sebagainya. Suatu reputasi perusahaan akan menurun manakala gagal dalam memenuhi apa yang disyaratkan pasar. (Herbig, Milewicz dan Golden, 1994).

\section{Kepuasan Konsumen}

Kepuasan konsumen merupakan tanggapan atas pemenuhan pelanggan terhadap sebuah pengalaman konsumsi, atau sebagian kecil dari pengalaman itu. Kepuasan pelanggan merupakan tanggapan yang menyenangkan dari pelanggan karena yang diharapkan terpenuhi, sedangkan ketidakpuasan merupakan tanggapan berupa kekecewaan karena yang diharapkan tidak terpenuhi. (Buttle, 2004; Kotler dan Keller, 2006; Arnould et al., 2005; Oliver, 1999)

\section{Loyalitas Konsumen}

Penelitian tentang loyalitas konsumen pada umumnya berpusat pada loyalitas konsumen terhadap tangible products, dan sering disebut sebagai brand loyalty. loyalitas konsumen pada umumnya merupakan suatu sikap yang merujuk pada ukuran keterkaitan konsumen terhadap pemilihan dan penggunaan suatu produk. Ukuran keterkaitan ini memberikan gambaran tentang penggunaan produk dalam waktu yang lama dan untuk masa yang akan datang, serta ukuran ini mampu mencerminkan peluang yang sangat kecil mengenai kemungkinan seorang konsumen beralih kepada penggunaan produk pesaing, apabila produk pesaing tersebut didapati adanya perubahan, baik menyangkut harga maupun atribut produk lainnya, (Oliver, 1999; Griffin, 2003; Pepper ddan Rogers, 2004).

\section{Kerangka Konsep}

Loyalitas konsumen merupakan suatu sikap pasca pembelian. Hal ini tidak serta-merta timbul. Sebelum konsumen dapat loyal terhadap suatu produk, konsumen akan mengevaluasi terlebih dahulu bagaimana produk yang telah dikonsumsinya. Hal ini dilakukan oleh konsumen untuk melihat baik apakah kualitas produk yang telah dikonsumsinya. Kerangka konsep yang digunakan dalam penelitian ini dapat dilihat pada Gambar 1. berikut ini.

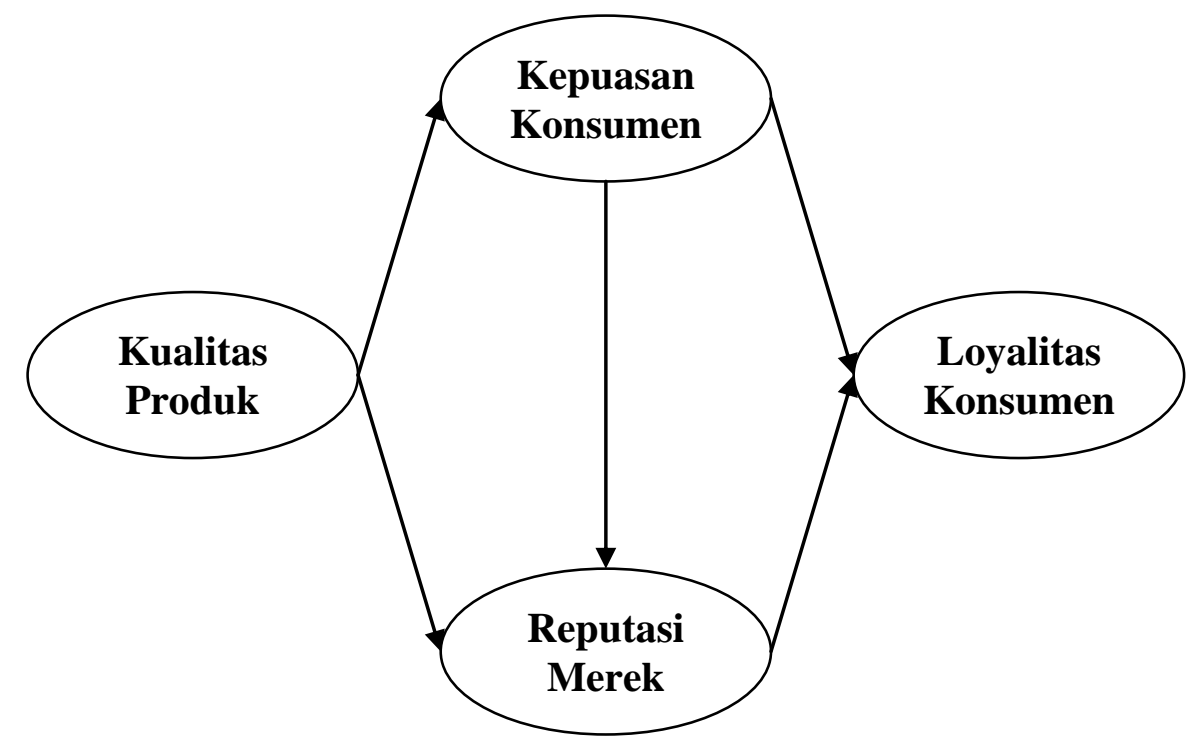

Gambar 1. Kerangka Konsep

Sumber: Diolah penulis berdasarkan hasil penelitian Fred Selnes (1993).

Jika produk yang dikonsumsinya berkualitas maka konsumen akan merasa puas terhadap produk tersebut dan bahkan secara langsung maupun tidak langsung akan meningkatkan reputasi merek dari produk tersebut. Hasil dari kepuasan konsumen dapat berpengaruh 
langsung maupun tidak langsung terhadap loyalitas konsumen. Hal inilah yang dalam penelitian ini akan diungkap secara lebih dalam.

\section{Hipotesis Penelitian}

Hipotesis penelitian yang dapat diajukan dalam penelitian ini berlandaskan pada model yang diajukan Selnes (1993). Adapun hipotesis tersebut adalah:

$\mathrm{H} 1$ : Kualitas produk berpengaruh positif terhadap kepuasan konsumen

$\mathrm{H} 2$ : Kualitas produk berpengaruh positif terhadap reputasi merek

H3: Kepuasan konsumen berpengaruh positif terhadap reputasi merek

H4: Kepuasan konsumen berpengaruh positif terhadap loyalitas konsumen

H5: Reputasi merek berpengaruh positif terhadap loyalitas konsumen

\section{METODE PENELITIAN}

\section{Sampel Penelitian}

Konsumen Jamu Tolak Angin PT. Sido Muncul merupakan populasi yang tidak terhitung (infinite), sehingga sulit diketahui ukuran populasinya. Berdasarkan hal itu, maka pada penelitian ini menggunakan teknik pengambilan sampel teknik sampling tidak acak (nonprobability sampling) dengan cara purposive sampling (sampling dengan tujuan) yaitu dengan mengambil sampel secara tidak acak dari populasi konsumen Jamu Tolak Angin PT. Sido Muncul yang ditemui saat mengkonsumsi produk tersebut di kios jamu di daerah Jakarta Utara. Ukuran sampel yang ditetapkan sebanyak 200 responden, hal ini berdasarkan pendapat Hair yang menyatakan ukuran sampel yang sesuai antara 100 hingga 200 (Hair et. al., 1998). Untuk melakukan uji instrumen digunakan 30 responden.

\section{Instrumen Penelitian}

Pengumpulan data dalam penelitian ini menggunakan alat bantu yang berupa instrumen penelitian. Instrumen tersebut mencakup seluruh variabel yang digunakan dalam penelitian ini yaitu (1) kualitas produk, (2) kepuasan konsumen, (3) reputasi merek dan (4) loyalitas konsumen. Semua instrumen tersebut dikembangkan oleh Fred Selnes dan dimodifikasi untuk disesuaikan dengan penelitian ini oleh peneliti. Untuk itu instrumen yang telah dimodifikasi harus diuji kembali validitas dan reliabilitasnya. Skala yang digunakan dalam instrumen penelitian ini adalah skala Likert, yang merupakan skala interval (Sekaran, 2006).

\section{Teknik Analisis Data}

Teknik analisis data dalam penelitian ini menggunakan teknik analisis deskriptif. Untuk pengujian hipotesis, penelitian ini menggunakan teknik analisis struktural equation model (SEM) yang diolah dengan bantuan program Lisrel.

\section{HASIL DAN PEMBAHASAN}

Hasil Penelitian

Penelitian ini dilakukan di daerah Jakarta Utara khususnya daerah Tanjung Priok, Sunter, Warakas, dan Cilingcing. Alasan pemilihan daerah tersebut adalah daerah yang banyak memiliki depot-depot jamu. Selain itu, daerah tersebut merupakan daerah yang memiliki aktivitas cukup tinggi selama 24 jam, karena daerah tersebut termasuk daerah pelabuhan yang menyerap banyak tenaga kerja.

Rentang usia terbanyak yang terambil menjadi responden dalam penelitian ini adalah 30 tahun hingga 45 tahun. Ini menunjukan bahwa rentang usia tersebut paling banyak ditemui pada saat pengambilan data. Hal tersebut dapat pula diakibatkan karena lokasi 
pengambilan data merupakan daerah pelabuhan yang banyak menggunakan tenaga kerja dengan rentang usia 30 tahun hingga 45 tahun.

\section{Model SEM dan Pembahasan}

Gambar 2 berikut ini merupakan hasil output dari standardized coeffisien yang dihasilkan dari data empiris untuk mengguji kembali model yang dikemukakan Selnes (1993). Sedangkan pada Gambar 3, merupakan uji † dari masing-masing standardized coefisien. Model pada penelitian ini memiliki goodness of fitdari model sebagai berikut: ChiSquare $=65.81 \quad(P=0.00026), R M S E A=0.071, G F I=0.94$, dan $A G F I=0.90$. Dari nilai goodness of fit tersebut dapat dikatakan bahwa model ini fit dengan data.

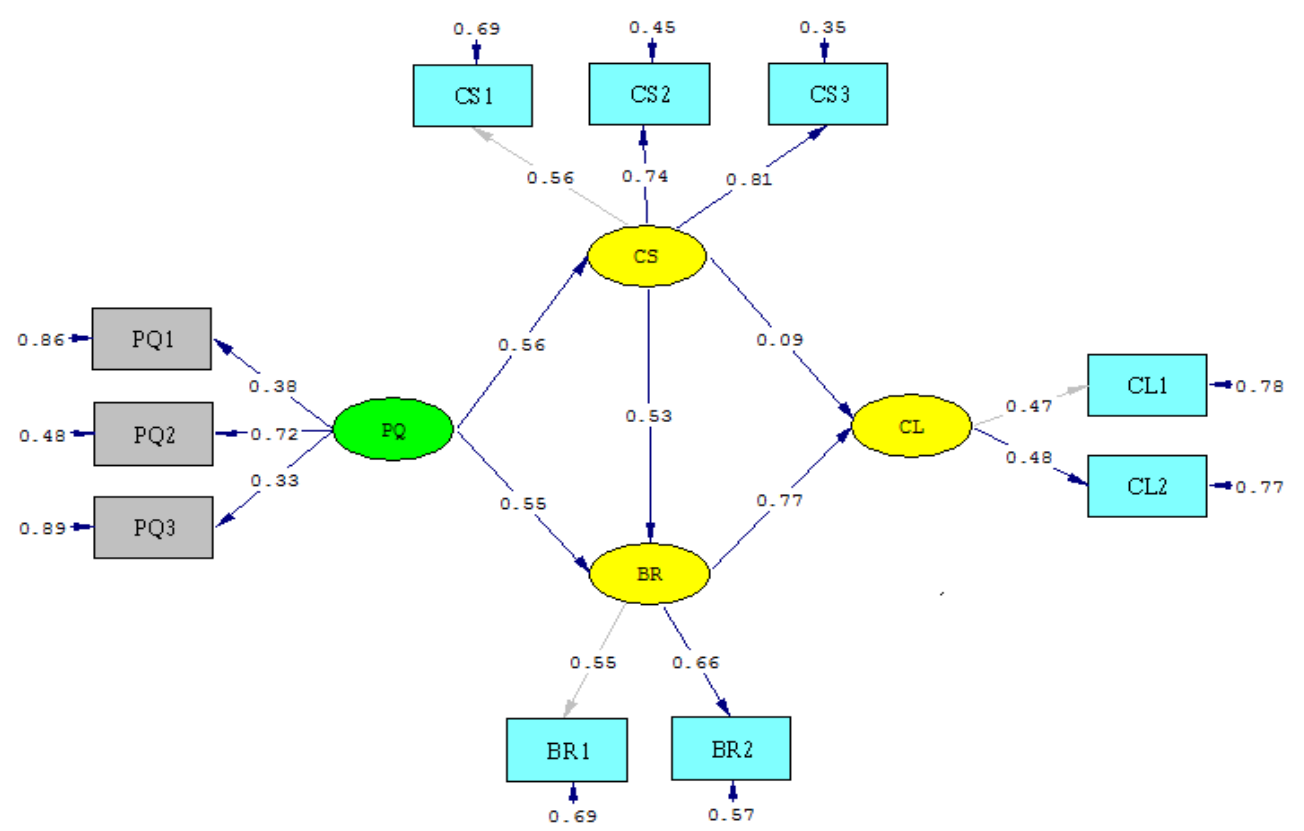

Gambar 2. Standardized Coeffisien

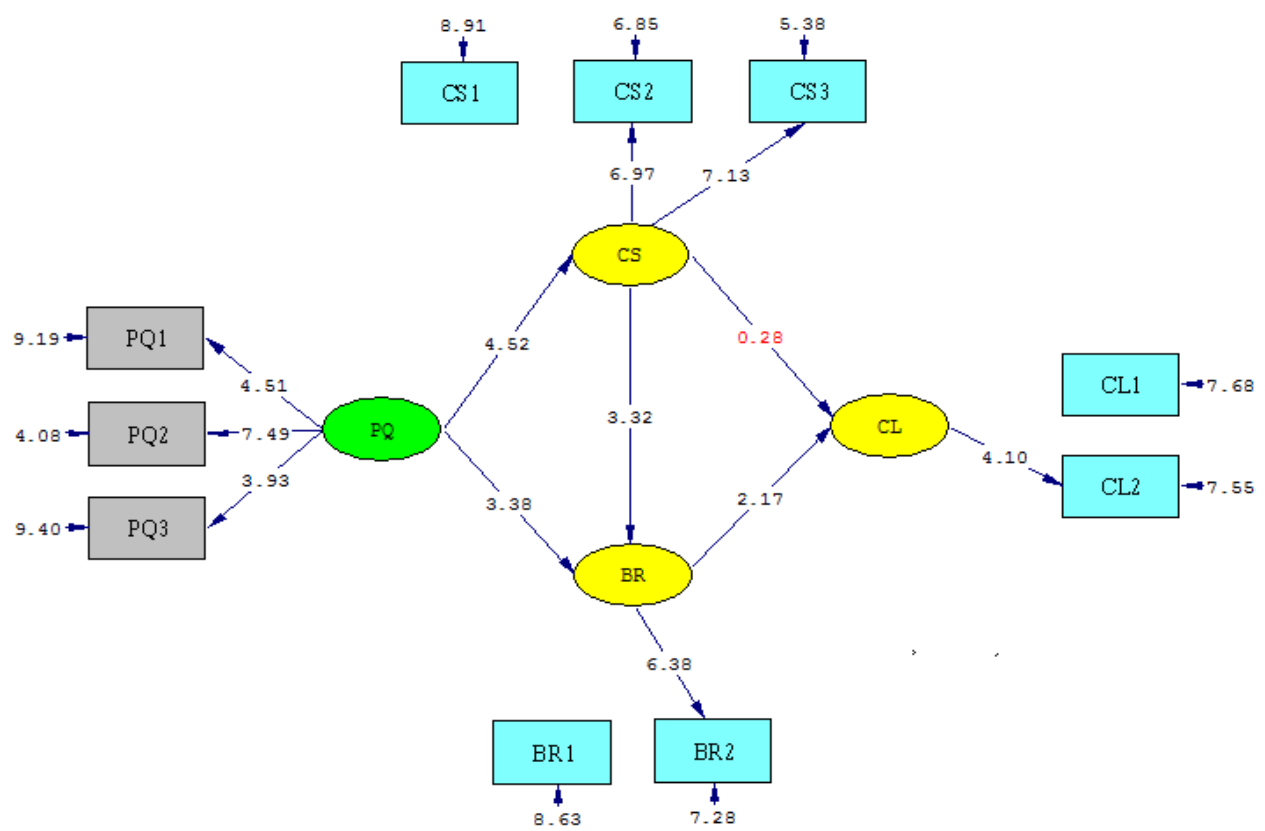

Gambar 3. Standardized Coeffisien 
Kualitas produk dari Jamu Tolak Angin PT. Sido Muncul dinilai baik oleh konsumen. Hal ini terlihat dari pengaruh langsung yang diberikan kualitas produk terhadap kepuasan konsumen sudah termasuk kuat. Kualitas produk dapat digunakan sebagai salah satu cara untuk meningkatkan kepuasan konsumen Jamu Tolak Angin PT. Sido Muncul. Kepuasan konsumen merupakan suatu evaluasi paska pembelian yaitu dengan membandingkan harapan konsumen dengan kenyataan yang diterimanya. Untuk selalu menjaga kepuasan konsumen maka Jamu Tolak Angin PT. Sido Muncul harus dapat mengetahui hal-hal yang menjadi harapan dari konsumen.

Kualitas produk Jamu Tolak Angin PT. Sido Muncul yang baik ternyata meningkatkan reputasi dari merek. Ini merupakan salah satu kunci keberhasilan dari suatu produk yang memiliki merek. Reputasi merek yang baik akan secara otomatis berada di benak konsumen. Ini akan membawa dampak positif bagi meningkatnya profit jangka panjang bagi Jamu Tolak Angin PT. Sido Muncul.

Kepuasan konsumen akan meningkatkan reputasi merek secara positif. Konsumen yang puas akan melakukan beberapa kegiatan seperti merekomendasikan produk terhadap kerabat, teman atau khalayak lainnya. Ini merupakan dampak langsung yang dapat dirasakan jika konsumen terpuaskan. Peningkatan reputasi merek ini diharapkan berlangsung secara terus-menerus, untuk itu Jamu Tolak Angin PT. Sido Muncul harus dapat mempertahankan bahkan meningkatkan kepuasan konsumennya.

Pada penelitian ini kepuasan konsumen tidak secara langsung mengakibatkan konsumen loyal. Hal ini dapat diakibatkan karena produk Jamu Tolak Angin PT. Sido Muncul tergolong pada convenience good, sehingga konsumen dapat mudah beralih ke produk sejenis dengan merek lainnya. Karakteristik convenience good dapat mengakibatkan kepuasan konsumen tidak secara langsung mempengaruhi loyalitas konsumen. Jamu Tolak Angin PT. Sido Muncul dapat memanfaatkan kepuasan konsumen ini sebagai titik tolak untuk menciptakan konsumen yang loyal meski melalui variabel lain sebagai intervening.

Reputasi merek yang baik akan mendorong konsumen untuk menjadi loyal terhadap produk Jamu Tolak Angin PT. Sido Muncul. Hal ini disebabkan reputasi merek yang baik merupakan hasil dari kualitas produk yang baik dan kepuasan konsumen yang tinggi, sehingga reputasi merek yang baik akan berdampak langsung terhadapa loyalitas konsumen Jamu Tolak Angin PT. Sido Muncul.

Kualitas produk yang baik secara langsung dapat meningkatkan kepuasan konsumen, namun di sisi lain kualitas produk yang baik dapat pula meningkatkan reputasi merek setelah konsumen tersebut puas. Hal ini merupakan suatu konseksuensi yang logis ketika konsumen yang puas karena mengkonsumsi produk dengan kualitas baik akan melakukan perekomendasian. Dari uji hipotesis ini dapat diketahui bahwa kualitas produk yang baik akan memberikan dampak secara langsung maupun tidak langsung terhadap reputasi merek Jamu Tolak Angin PT. Sido Muncul.

Kualitas produk yang baik akan meningkatkan kepuasan konsumen, namun kepuasan konsumen yang tinggi tidak serta-merta mengakibatkan konsumen menjadi loyal. Pada pengujian hipotesis keempat di atas telah dijabarkan bahwa Jamu Tolak Angin PT. Sido Muncul tergolong convenience good sehingga konsumen dapat mudah berpindah dari satu merek ke merek lain.

Kualitas produk Jamu Tolak Angin PT. Sido Muncul berpengaruh terhadap loyalitas konsumen melalui reputasi merek. Pengaruh ini terjadi karena konsumen akan semakin loyal jika mengetahui produk yang dikonsumsinya memiliki kualitas yang baik dan reputasi merek yang baik. Agar konsumen tetap loyal terhadap produk Jamu Tolak Angin PT. Sido Muncul, 
produsen sebaiknya memperhatikan kualitas produk dan reputasi mereknya benak stakeholder saat ini.

Kepuasan konsumen yang merupakan evaluasi paska konsumsi berpengaruh secara tidak langsung terhadap loyalitas konsumen melalui reputasi merek. Dalam model yang dimodifikasi, konsumen yang puas akan menjadi loyal setelah mengetahui bahwa Jamu Tolak Angin PT. Sido Muncul memiliki reputasi merek yang baik. Banyaknya produk jamu sejenis dapat mengakibatkan konsumen berpindah terhadap merek lain. Untuk itu reputasi merek yang baik sangat penting dan menentukan konsumen akan loyal atau tidak, selain kepuasan konsumen.

Kualitas produk yang baik akan membuat konsumen puas, reputasi merek meningkat dan konsumen akan loyal. Kualitas produk merupakan satu-satunya variabel eksogen dalam penelitian ini atau dengan kata lain kualitas produk merupakan variabel awal yang mempengaruhi variabel lainnya. Kualitas produk ternyata menjadi awal untuk menciptakan konsumen yang loyal melalui kepuasan konsumen dan reputasi merek terlebih dahulu.

Pada penelitian ini menganalisis 4 (empat) variabel yaitu kualitas produk, kepuasan konsumen, reputasi merek dan loyalitas konsumen. Model yang dihipotesiskan maupun model tahap dua memiliki 3 (dua) struktur persamaan jalur. Adapun struktur persamaan yang pertama, kualitas produk berpengaruh terhadap kepuasan kerja. Struktur persamaan yang kedua, kualitas produk dan kepuasan konsumen berpengaruh terhadap reputasi merek. Struktur persamaan yang ketiga, kepuasan konsumen dan reputasi merek berpengaruh terhadap loyalitas konsumen.

Hasil perhitungan koefisien dalam model yang dihipotesiskan menunjukan adanya jalur yang tidak signifikan, kualitas produk dan kepuasan konsumen berpengaruh langsung terhadap, reputasi merek. Pengaruh kepuasan konsumen lebih besar jika dibandingkan dengan kualitas produk terhadap reputasi merek. Namun dilihat dari koefisiennya, kepuasan konsumen tidak secara dominan berbeda dengan kualitas produk, oleh karena itu untuk meningkatan reputasi merek harus dilakukan dengan memperhatikan dan meningkatkan kualitas produk dan kepuasan konsumen.

\section{KESIMPULAN}

Berdasarkan hasil analisis pada bab sebelumnya, maka dapat disimpulkan bahwa variasi loyalitas konsumen dipengaruhi baik secara langsung maupun secara tidak langsung oleh variasi berbagai variabel di antaranya kualitas produk, kepuasan konsumen dan reputasi merek. Ini berarti bahwa loyalitas konsumen dapat ditingkatkan dengan memperhatikan kualitas produk, kepuasan konsumen dan reputasi merek dari Jamu Tolak Angin PT. Sido Muncul.

\section{KETERBATASAN PENELITIAN}

Penulis menyadari bahwa pada penelitian ini sarat dengan keterbatasan. Keterbatasan itu menyangkut beberapa hal seperti konsep, metodologi dan teknis penelitian. Keterbatasan secara konseptual pada penelitian ini terletak pada pengujian model yang masih sederhana.

Keterbasan berikutnya adalah penggunaan pendekatan metode kuantitatif pada penelitian ini. Penggunakan alat statistik untuk menganalisis variabel-variabel yang bersifat kualitatif yang dikuantifikasikan maka hasil dari penelitian ini akan sarat dengan kelemahan. Pendekatan metode ini tidak dapat menggali informasi secara mendalam untuk tiap variabel yang diteliti. Terkadang teknik statistik menggunakan banyak penyederhanaan sehingga dapat mengakibatkan kurangnya ketelitian dalam penelitian ini. 
Adanya keterbatasan dalam penelitian ini, diharapkan pada penelitian berikutnya agar dapat dikembangkan lagi penggunaan konsep, metodologi dan teknis pelaksanaan penelitian secara lebih baik agar penelitian yang dihasilkan lebih berdaya guna.

\section{SARAN}

Dari kesimpulan hasil penelitian di atas, penulis akan menyampaikan beberapa saran berkenaan dengan model loyalitas konsumen untuk Jamu Tolak Angin PT. Sido Muncul dalam rangka meningkatkan loyalitas konsumen jamunya. Kualitas produk merupakan aspek penting yang mempengaruhi loyalitas konsumen, untuk itu kualitas produk harus dapat ditingkatkan lagi. Mengingat varian jamu sejenis dengan merek lain bermunculan, PT. Sido Muncul harus menunjukan bahwa produknya yang terbaik. Hal ini merupakan suatu keharusan bagi perusahaan yang ingin menjadi pimpinan di pasar.

Perubahan harapan konsumen akan produk dapat mengakibatkan perubahan tingkat kepuasan konsumen. Hal ini sangat mungkin terjadi karena arus informasi yang sangat tinggi dapat mengakibatkan perubahan harapan yang sangat cepat. Agar perusahaan dapat mempertahankannya, perusahaan harus melakukan penelitian kepuasan konsumen secara terus menerus.

Penelitian berikutnya hendaknya tidak hanya mereplikasi model yang dikemukakan oleh Selnes (1993) ini melainkan menambah variabel-variabel lain untuk mengetahui model loyalitas konsumen yang semakin mendekati kenyataannya.

\section{DAFTAR PUSTAKA}

Ahyari, A. 1990. Management Produksi. Yogyakarta: BPFE

Arnould, Eric, Linda Price and George Zinkhan. 2005.Consumers. Second Edition. Singapore: McGraw-Hill Education (Asia).

Assauri, S. 1998. Manajemen Produksi dan Operasi. Edisi Revisi. Jakarta: LPFEUI

Bennett, Roger and Helen Gabriel. 2001. Reputation, Trust and Supplier Commitment: the Case of Shipping Company/Seaport Relations. The Journal of Business \& Industrial Marketing. Vol. 16(6): 424-438.

Buttle, Francis. 2004. Customer Relationship Management: Concepts and Tools. First published. Oxford: Elsevier Butterworth-Heinemann.

Dharmmesta, Basu Swastha dan T. Hani Handoko. 2000. Manajemen Pemasaran: Analisa Perilaku Konsumen. Edisi Pertama. Yogyakarta: BPFE-Yogyakarta.

Griffin, Jill. 1995. Customer Loyalty: How to Earn It, How to Keep It. New York: Simon and Schuster, Inc.

Hair, J. F., R. E. Anderson, R.L. Tatham and W. C. Black. 1998. Multivariate Data Analysis. Fifth Edition. New Jersey: Prentice-Hall, Inc

Haywood, Roger. 2005. Corporate Reputation, The Brand \& The Bottom Line.Third Edition. London: Kogan Page Limited.

Herbig, Paul and John Milewicz. 1995. The Relationship of Reputation and Credibility to Brand Success. The Journal of Consumer Marketing. Vol. 12(4): 5-10.

Herbig, Paul, John Milewicz and Jim Golden, 1994, "A Model of Reputation Building and Destruction", Journal of Business Research, Vol.31, June1994, No.1; p.23-31

Oliver, Richard L., 1993, "Cognitive, Affective and Attribute Base of the Satisfaction Response", journal of consumer research, p.18-30.

Oliver, R.L. 1999. Whence Consumer Loyalty. Journal of Marketing, Vol. 63, pp. 33-44. 
Peppers, Don and Martha Rogers. 2004. Managing Customer Relationships: A Strategic Framework. New Jersey: John Wiley \& Sons, Inc.

Sekaran, Uma. 2003. Research Methods for Business. Fourth Edition. New York: John Wiley \& Sons, Inc.

Selnes, Fred, 1993, "An Examination the Effect of Product Performance on Brand Reputation, Satisfaction and Loyalty", European Journal of Marketing, vol. 27, no. 9, p.19-35. 